Current Issues in Middle Level Education

Volume 25 $\mid$ Issue 2

Article 6

2020

\title{
Modeling Flexibility for Middle Level Teacher Candidates during the COVID-19 Pandemic
}

Leah L. Kahn

Stephen F Austin State University, llkahn@sfasu.edu

Michelle Williams

Stephen F. Austin State University, williamsdm@sfasu.edu

Follow this and additional works at: https://digitalcommons.georgiasouthern.edu/cimle

Part of the Junior High, Intermediate, Middle School Education and Teaching Commons, and the Scholarship of Teaching and Learning Commons

\section{Recommended Citation}

Kahn, Leah L. and Williams, Michelle (2020) "Modeling Flexibility for Middle Level Teacher Candidates during the COVID-19 Pandemic," Current Issues in Middle Level Education: Vol. 25 : Iss. 2 , Article 6.

DOI: $10.20429 /$ cimle.2021.250206

Available at: https://digitalcommons.georgiasouthern.edu/cimle/vol25/iss2/6

This best practices is brought to you for free and open access by the Journals at Digital Commons@Georgia Southern. It has been accepted for inclusion in Current Issues in Middle Level Education by an authorized administrator of Digital Commons@Georgia Southern. For more information, please contact digitalcommons@georgiasouthern.edu. 


\title{
Modeling Flexibility for Middle Level Teacher Candidates during the COVID-19 Pandemic
}

\author{
Leah L. Kahn \\ Michelle Williams \\ Stephen F. Austin State University
}

\begin{abstract}
Faced with school closures in the spring of 2020 due to COVID-19, middle level teacher candidates were left with no way to finish their field experiences. The challenge continued into the fall with many schools providing only virtual learning and some not allowing visitors on campus. This article describes the steps one university middle level program implemented to create an engaging, meaningful field experience while modeling flexibility for the teacher candidates.
\end{abstract}

\section{Introduction}

On March 5, 2020, teacher candidates left for spring break, ready for some rest but unprepared for what the remainder of the semester would bring. Due to the spread of the Novel Coronavirus disease (COVID-19), the university made the decision that students would not return to campus and would complete the rest of the semester in online instruction. Public schools also shut down during this time. This shutdown created a particular challenge for faculty supervising field experience courses. Concerns about teacher candidates completing the required hours in the classroom were real. The Texas Education Agency (TEA) (2020) announced modifications in the required face-to-face field experience hours due to the COVID-19 shut down. Middle level grades program requirements at our university were greater than the minimum required by TEA, and some teacher candidates had met the TEA minimum by spring break. However, many teacher candidates had not yet taught the required lessons.

The field experience supervisors quickly realized that flexibility and offering more choice during this bizarre period in education would be necessary for our teacher candidates to successfully complete the field experience. As middle level teacher educators, we emphasize the importance of flexibility, adjusting instruction to students' needs, and providing student choice as we prepare our teacher candidates for the classroom. Being responsive to student needs is one of the five essential attributes of successful middle level schools, and the concept of student choice is part of the 18 characteristics (Bishop \& Harrison, 2021). This situation presented us with an extraordinary opportunity to model the implementation of these attributes to our teacher candidates. In the sections that follow, we will review the middle level grade field experience requirements and how the program modified the experience with the spring shut down and the uncertainty of the status of schools for the fall of 2020.

\section{The Field Experience}

The Middle Level Program at the university takes pride in the number of hours our teacher candidates spend in the classroom. In Field Experience I (FE I), teacher candidates are required to be in the mentor teacher's classroom for 90 hours. In Field Experience II (FE II) they 
are required to double this number and be in the classroom for a total of 180 hours. In Texas, pre-service teachers are only required to receive 30 hours of experience in the classroom before clinical teaching, so our teacher candidates complete well beyond the minimal requirements (TEA, 2020). When recruiting for our university and program, one of our selling points is the number of hours teacher candidates spend in the classroom working with a mentor teacher and middle school students.

During FE I, teacher candidates are placed in a fourth or fifth grade classroom, and in Field Experience II, they are in a sixth, seventh, or eighth grade classroom. FE I teacher candidates are typically in the classroom two mornings per week, and FE II teacher candidates are typically in the classroom for two full days a week. Teacher candidates are required to teach one lesson to be observed by the field experience supervisor in FE I and three lessons to be observed in FE II.

\section{Spring 2020 Shut Down}

As soon as the university announced that the remainder of the semester would be online, the middle level program faculty began making plans as to how to proceed with the courses and FE labs to best meet the needs of the teacher candidates, while still maintaining requirements and standards. Public schools were shut down, and our mentor teachers were dealing with their own challenges. A few our teacher candidates contacted their mentors to assist as the teachers planned for the students to work at home (either online or with packets of work) with little response. Texas Education Agency (TEA, 2020) waived the requirement that field experience hours had to be at the school site and allowed for virtual experiences.

TEA also provided a resource for universities as an alternative for teacher candidates to complete field experience hours. This resource, Texas Teach Like A Champion (TLAC), is an online program that includes videos, readings, and tasks related to effective teaching. This website includes 24 modules covering 13 techniques in three categories. The three broad categories are Behavior and Culture, Planning for Achievement, and Engaging Academics (TEA, Texas TLAC Online). At the end of each module, the teacher candidate completes a task, which generally requires them to submit a video of themselves modeling the teaching strategy for the field experience supervisor. For example, in the module titled Non-Verbal Intervention, teacher candidates view a short video of a teacher modeling non-verbal interventions in a reading lesson. They are asked to consider how the flow of the lesson would change if the teacher used verbal interventions instead. Within the module, teacher candidates also view a short video of an interview with another teacher on how she uses non-verbal interventions to encourage student voice in her classroom. Finally, teacher candidates are prompted to create five videos of themselves practicing non-verbal interventions based on five different classroom scenarios. The field experience supervisors developed a plan for teacher candidates to complete units of TLAC to replace any lesson/observation not completed before the shutdown. The teacher candidates were required to complete eight modules of the 24, of their choice, of TLAC in place of each required lesson/observation. At the end of each module, they submitted the completed task to the field experience supervisor.

Fortunately, since our university has an online program with a comparable online course on the same timeline, professors were able to upload the online content into the face-to-face course shell on Brightspace (online platform). This allowed face-to-face teacher candidates to continue to progress through the course in the online format. Most teacher candidates had 
completed approximately half of the hours required by the program and met the minimum hours required by the state. Field experience supervisors met with individual teacher candidates to review their progress before the shutdown and verify the number of TLAC modules required to complete the lab course. Accommodations were made for specific assignments to be completed in the schools that had not been completed before the shutdown. Each candidate's plan to complete the course was unique to his/her circumstances, modeling for the teacher candidates the concept of "fair" means everyone gets what they need. For example, in FE I, students complete a shadow study that includes following a student throughout his entire day in conjunction with the Response to Intervention (RTI) section of the course and write a paper describing the students, his/her needs, interventions, etc. Most were unable to complete the assignment before the shutdown. The assignment was modified to allow the teacher candidate to write the paper based on observations in the mentor's class before the shutdown. In FE II, teacher candidates complete a work sample assignment that includes pre- and post-assessment, a video lesson, peer review and reflection of student learning. The field experience supervisor met individually with each student to determine what components of the assignment were possible to complete. Each teacher candidate's work sample requirement was somewhat different in expectation and possible points. This individualized approach was crucial in teacher candidates' successful completion of the spring field experience courses and labs.

\section{Fall 2020}

Throughout the summer of 2020, faculty received mixed messages about the availability of schools for field experience placements. The faculty met and made plans for various scenarios in anticipation of further shutdowns or schools not allowing university students in the schools. Fortunately, many schools were back in session and allowed teacher candidates' placements. Our university decided that university students would have the option of coming back to campus or taking all courses online at home. This situation, of course, became another challenge for the field experience supervisors. Teacher candidates who would ordinarily be in our local public schools were forced to secure their own placements in their hometowns. Arranging their own placements is the standard procedure for our online program teacher candidates. Securing placements proved to be challenging for some, and with COVID-19 restrictions in place, many schools were not allowing any visitors. We were initially told that our local schools were not allowing any teacher candidate placements other than clinical teaching. This, again, required the faculty to make modifications based on the individual teacher candidate's need. The faculty met to discuss how to best meet the field experience requirements in a variety of possible scenarios. The faculty developed a continuum of expectations for each field experience. Field Experience I (usually 8 hours per week and one lesson observation) continuum included:

1) The teacher candidate would be assigned (or if outside of the area, secure their own) to a mentor in a fourth or fifth grade classroom and complete eight hours per week.

2) The teacher candidate will observe a minimum of four class periods per week. This can be the regularly scheduled zoom sessions with designated teachers or watching videos (Charter or other designated teachers)

The requirement for teaching a lesson to be observed by the field experience supervisor was also set up as a continuum. 
1) Teacher candidates in FE I (virtually or face-to-face) will teach one lesson to be observed by the field experience supervisor.

2) If it was not possible for the candidate to teach the class face-to-face or virtually, the candidate could teach a lesson virtually to his/her FE I classmates.

3) Finally, if it was not possible to teach a lesson to the assigned mentor's class or peers, the candidate would complete eight modules on the TLAC site.

The continuum for Field Experience II (usually 16 hours per week and observed teaching three lessons) included:

1) The teacher candidate completes 16 hours per week in a mentor's classroom in grades 4-8 and teaches three lessons to be observed by the professor. If this is not possible,

2) The teacher candidate observes eight class periods per week (live stream or recordings) of lessons from Charter School or other teachers and teaches at least one lesson (face-to-face or virtually) to be observed by the university supervisor. The teacher candidate makes up for missing lessons by teaching to his or her peers or completing eight modules of TLAC to replace the other required observations. Most teacher candidates had completed eight modules in FE 1 in the spring and could potentially do the 16 remaining modules in FE II.

In anticipation of the need for virtual teaching in the fall, our FE I supervisor developed a virtual teaching module to assist teacher candidates as they prepared to teach in the online setting. This module provided tips on teaching effectively online and contained many links to articles and videos for teacher candidates to use as a resource as needed. By this time in the pandemic, information about best practices in teaching online had flooded teacher websites and social media sites. Previously, courses in the middle level program did not include any resources or modules for teaching virtually, and we saw this as an immediate need for our teacher candidates.

Along with all the changes we were hastily putting in place for our teacher candidates during this unprecedented time, we were also facing, as many universities were, drastic budget cuts due to the pandemic. The middle level program faculty discussed purchasing simulation software to use with teacher candidates so that they could use this, or part of this, as their experience in the field. Unfortunately, the cost was prohibitive, and it was not possible to purchase such a program.

\section{The Reality of Fall 2020}

University faculty members had been instructed to hold off on the placement of teacher candidates throughout the summer. Ordinarily, we begin making placements for fall early in the summer. Finally, in mid-August, we were able to contact our partner schools concerning our field experience placements. While each school varied, in its approach to COVID-19 and virtual learning, most were providing both face-to-face and virtual options for their students. The faceto-face teacher candidates were placed in the usual sites in local schools near campus. This was not mandatory, and it was made clear that if they did not feel comfortable being in schools because of COVID-19, the field experience supervisor would work with the teacher candidate to locate a virtual alternative. Online teacher candidates and those who were usually face-to-face but were staying at home for the semester secured their placements in their local school districts. 
The sections that follow describe the various circumstances in which teacher candidates completed their field experience expectations.

\section{Face-to-Face}

Teacher candidates who were on or near campus were placed with mentors in local schools near the university. Many of those candidates were paired with teachers who taught a traditional face-to-face class, while others were with teachers who were teaching both face-toface and virtually (at the same time). Teacher candidates were encouraged to schedule their lesson/observations early in the semester in the event of another shutdown.

Teacher candidates in face-to-face classrooms faced challenges throughout the semester. For example, there were times when they had to quarantine, or schools shut down for periods of time. While some of these candidates were able to continue their observation hours by joining their mentors virtually (if the mentor was teaching both face-to-face and virtually), others were not able to do so. To assist the candidates in getting the required hours they needed during these times when they could not access a school, we were able to use the University Charter School. The Department of Education Studies at the university is connected to the Charter School, which serves kindergarten through fifth grade students. Fourth and fifth grade teachers graciously provided videos of themselves teaching lessons. These lessons were anywhere from 20 to 45 minutes in length. The lessons were uploaded to the lab course so that teacher candidates could use them as observation hours if they were quarantined or if their school had to shut down due to an increase in COVID-19 cases. Additionally, the university purchased a subscription to The Teaching Channel, so when teacher candidates were not able to participate in schools for periods of time due to COVID conditions, they could view videos to add to their required hours.

\section{Virtual Teaching - Synchronous}

Several of our middle level teacher candidates were matched with mentor teachers who were teaching in a virtual live-streamed classroom. One middle school had teachers who were assigned only to teach virtually. Teacher candidates in that situation had to teach their required lessons in that virtual environment with little preparation other than the virtual module created for this semester. This situation proved to be a great learning experience as the teacher candidate learned to plan engaging virtual activities for the middle level students. The challenge came as middle students moved back and forth between virtual and face-to-face classrooms. The students in the middle school classes were continually changing. It was also challenging to develop a lesson virtually that would meet all the expectations of the required work sample lesson in FE II.

\section{Virtual teaching - Asynchronous}

The most frustrating situation was when a teacher candidate lived in a district that was not allowing visitors or teacher candidates in the schools. Online teacher candidates who did not live near the university sites and were not allowed in their local schools faced the biggest challenge. There were a couple of our partner districts willing to allow teacher candidates to participate either face-to-face or virtually. However, there were often problems with bandwidth for live-stream observations, problems with video permissions, and with the distance that teacher candidates would need to travel to observe and teach face-to-face. A solution for this scenario was placing a teacher candidate with a mentor who was teaching online in an asynchronous classroom. In this case, the teacher candidate was given permission to join the online class platform. The mentor teacher coached the teacher candidate via email and phone and allowed 
the teacher candidate to review (observe) her online lessons and create and upload lessons to the online platform for the mentor's students. This situation ended up being highly successful as the mentor teacher involved was an exceptional teacher; the teacher candidate learned a lot about the online platform, which was CANVAS. The teacher candidate in the asynchronous situation supplemented her observation hours by viewing the videos provided in the course provided by the university's Charter School teachers.

\section{The Future}

During the fall semester, many of our middle level teacher candidates appeared to be grateful for the opportunity to be placed face-to-face in middle level classrooms and to meet on a regular basis with their peers and field experience supervisor via Zoom, especially after their experience in the spring. As we move toward the 2021 spring semester, the middle level program faculty are unsure as to how the spring semester will play out, just as we were with the fall 2020 semester. COVID-19 cases are surging across the state, and with winter approaching, the outlook does not look favorable for face-to-face placements. We may be forced to begin the semester with teacher candidates only participating in virtual experiences and then gradually and carefully begin placing teacher candidates face-to-face in classrooms as the semester progresses. Handling each teacher candidate's situation on an individualized basis, with flexibility and care, worked well for us during the fall semester. We are hopeful that it can work again for us in the spring. The teacher candidates, for the most part, had quality experiences in fourth through eighth classrooms, both locally and across the state.

\section{Conclusion}

Things we have learned through this pandemic include the importance of continuing to include research-driven, best practice approaches to teaching middle school students virtually, post COVID-19, in our coursework. Keeping this as part of our curriculum is critical because we do not know what the future holds for in-school learning. There are so many unknowns right now, and it will take time to see the results of the research as we are living through this event right now. Classroom teachers were caught entirely off guard when the pandemic hit in the early spring of 2020. Most had never taught using online platforms and had to learn very quickly, hence the need to prepare our middle level teacher candidates for both virtual and face-to-face teaching modalities in the future.

Additionally, although we felt we were flexible and offered choices to our teacher candidates before COVID-19, we have seen, first-hand, the benefits to our teacher candidates of providing more flexibility and alternatives to meet individual needs. The current COVID-19 situation has provided an opportunity for our faculty to model this for our teacher candidates. As we move forward into 2021, we must continue to engage our teacher candidates in meaningful field experiences to prepare them for a continually changing classroom.

\section{References}

Bishop, P. A \& Harrison, L. M. (2021). The successful middle school: This we believe. Association for Middle Level Education.

Teaching Channel (2020) https://teachingchannel.com. 
Texas Education Agency. (March, 2020). FAQ and updates for EPPs. Texas Education Agency. Texas Education Agency. (n.d.) Texas TLAC online. https://texastlaconline.org/. 